\title{
ANALISA DAN PEMODELAN PERANGKAT LUNAK EPOINT KEMAHASISWAAN SEBAGAI PENDUKUNG SKPI DI UNIVERSITAS KATOLIK WIDYA KARYA MALANG
}

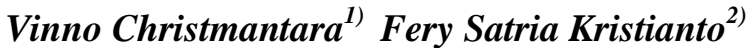 \\ ${ }^{1,2)}$ Program DIII Manajemen Informatika, Unika Widya Karya Malang, Jl.Bondowoso 2 Malang, \\ Indonesia \\ email:vinno@widyakarya.ac.id ${ }^{1)}$,fery@widyakarya.ac.id ${ }^{2)}$
}

\begin{abstract}
Abstrak
SKPI adalah salah satu prasyarat untuk ijazah pendukung yang didalamnya terdapat unsur pendukung, salah satunya adalah kegiatan yang diikuti oleh siswa baik akademik maupun non akademik. Di UKWK sendiri, proses pencatatan kegiatan siswa masih dilakukan secara manual sehingga membutuhkan waktu untuk proses pencarian dan validasi. Prototipe desain sistem informasi siswa berbasis web ini dapat membantu siswa dalam mendukung perekaman aktivitas siswa yang terkomputerisasi. Dalam penelitian ini, ada 3 peran pengguna utama yang mengambil bagian dalam sistem, yaitu tingkat biro siswa, tingkat departemen dan tingkat siswa. Pada tingkat biro siswa dan jurusan memiliki wewenang untuk memvalidasi data dari siswa. Sementara di tingkat siswa, hanya dalam sistem ini dibagi menjadi 2 penilaian, yaitu jenis kegiatan dan peran dalam kegiatan tersebut. Dari hasil penentuan bobot tersebut, diharapkan setiap aktivitas aktivitas siswa memiliki poin dan dicatat dalam database sehingga dapat digunakan sebagai elemen pendukung dalam pembuatan SKPI.
\end{abstract}

\section{Kata Kunci :}

SKPI, points, assessments.

\begin{abstract}
SKPI is one of the prerequisites for supporting diplomas in which there are supporting elements, one of which is the activities followed by students both academic and non-academic. At UKWK itself, the process of recording student activities is still done manually so that it takes time for the search and validation process. This websitebased student information system design prototype ePoint student can help in supporting computerized student activity recording. In this study, there were 3 roles of the main users who took part in the system, namely the level of the student bureau, the level of department and student level. At the level of the student bureau and majors have the authority to validate data from students. While at the student level, only in this system is divided into 2 assessments, namely the type of activity and role in the activity. From the results of the determination of the weighting, it is expected that each student activity activity has points and is recorded in the database so that it can be used as a supporting element in making the SKPI.
\end{abstract}

\section{Keywords :}

SKPI, points, assessments.

\section{PENDAHULUAN}

Perkembangan pendidikan tinggi saat ini mengalami perubahan paradigma sejak diberlakukan Kerangka Kualifikasi Nasional Indonesia (KKNI). Melalui Permendikbud Nomor 81 Tahun 2014 setiap lulusan perguruan tinggi akan diberikan paling sedikit 2 (dua) dokumen Ijazah (yang tertuang pada Pasal 5 ayat 1) berupa Transkip Akademik dan SKPI (Surat Keterangan Pendamping Ijazah). SKPI adalah dokumen yang memberikan informasi tentang pencapaian akademik atau kualifikasi dari lulusan pendidkan tinggi bergelar yang diuraikan secara deskriptif sesuai dengan jenjang KKNI yang relevan (Kemendikbud, Tahun 2014).

Pemberlakuan SKPI menjadi permasalahan baru setiap perguruan tinggi di Indonesia, hal ini juga dialami oleh Universitas Katolik Widya Karya (UKWK) Malang. Permasalahan utama terletak pada sumber data kualifikasi dalam penyusunan dokumen SKPI. Sumber data kualifkasi terdiri dari jenjang pendidikan, skema pendidikan tinggi, sistem penilaian prestasi dan keaktifan mahasiswa selama masa studi. Terutama data penilaian prestasi dan keaktifan 
mahasiswa selama ini masih tercatat manual yang dilakukan oleh biro kemahasiswaan. Hal ini menjadi permasalahan tersendiri karena dibutuhkan waktu untuk melacak dan pemberian penilaian untuk setiap rekam aktifitas mahasiswa

Dengan pemanfaatan teknologi informasi, hal tersebut dapat diatasi dengan membangun sebuah sistem informasi penilaian yang diberi nama ePoint. ePoint adalah sebuah aplikasi berbasis website yang dapat diakses oleh mahasiswa dan Biro Kemahasiswaan UKWK secara online. Aplikasi ini diharapkan dapat menampung seluruh data mengenai aktivitas kemahasiswaan dari seorang mahasiswa, dan penilaian yang berbentuk poin yang merupakan hasil validasi oleh Biro Kemahasiswaan UKWK. Data yang lengkap ini akan diproses menjadi infomasi yang mendukung penyusunan dokumen SKPI sebagai pendamping ijazah. Tujuan penelitian ini adalah untuk menganalisa alur proses yang efisien dan merancang serta membangun perangkat lunak yang dapat mencatat dan memberikan penilaian untuk setiap aktifitas mahasiswa selama masa studinya).

\section{METODE / ALGORITMA}

\subsection{Rancangan Penelitian}

Secara umum, tahapan rancangan penelitian akan dibagi menjadi:

a. Pembuatan sistem informasi ePOint, yang terdiri dari administrator antarmuka sesuai akses pegguna. Akses pengguna di bagi menjadi 4 kriteria level pengguna: Kemahasiswaan, Jurusan , Mahasiswa dan Super administrator.

b. Pengambilan data dan dokumen pendukung kepada para ahli yaitu Wakil Rektor I dan Biro Kemahasiswaan Universitas Katolik Widya Karya (UKWK) serta para Ke. Jurusan/Prodi.

c. Melakukan analisa aktifitas masing-masing level pengguna.

d. Melakukan analisa dan perancangan database : table dan field-field

e. Pembuatan master pembobotan nilai aktivitas kemahasiswaan

f. Sistem akan menghasilkan output berupa rekapitulasi aktifitas kemahasiwaan untuk setiap mahasiswa

Dalam proses perancangan sistem informasi ePoint (tahapan ke-1 rancangan penelitian), peneliti akan mengimplementasikan metode klasikal waterfall (Pressman S, 2010). Metode waterfall memiliki beberapa tahapan yang runtut yaitu 1. requirement (analisis kebutuhan), 2 . system design (desain sistem), 3. coding and testing (pemrograman), 4. implementation (penerapan program), dan 5. operation and maintenance (pemeliharaan).

Langkah awal adalah melakukan analisa kebutuhan terhadap sistem yang akan dibangun. Analisa dilakukan dengan cara:

- Wawancara dengan Biro Kemahasiswaan UKWK untuk mendapatkan gambaran kebutuhan terkait proses pelaksanaan penilaian aktivitas mahasiswa berdasarkan sistem poin

- Studi literatur seputar Permendikbud Nomor 81 Tahun 2014 yang mengatur pelaksanaan penerbitan dokumen SKPI sebagai dokumen pendamping ijazah

- Studi literatur seputar KKNI level 6 dan level 7 untuk mendapatkan karakter mahasiswa yang akan dicantumkan pada dokumen SKPI (SKPI, 2017)

- Observasi terhadap sistem serupa pada institusi lain yang telah berjalan, yaitu aplikasi kemahasiswaan STTS yang dapat diakses melalui http://kemahasiswaan.stts.edu 

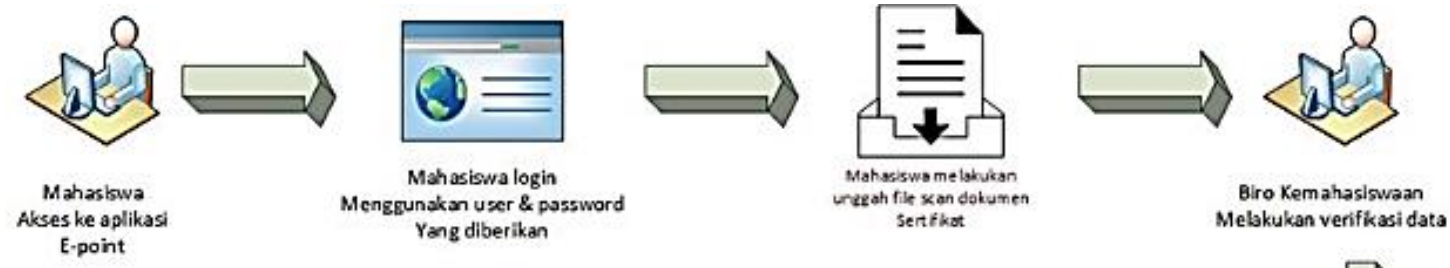
-point
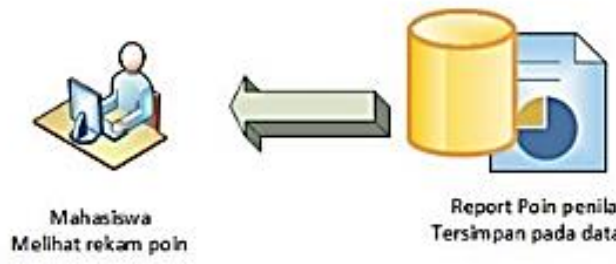

Report Poin penilaian Tersimpan pada database
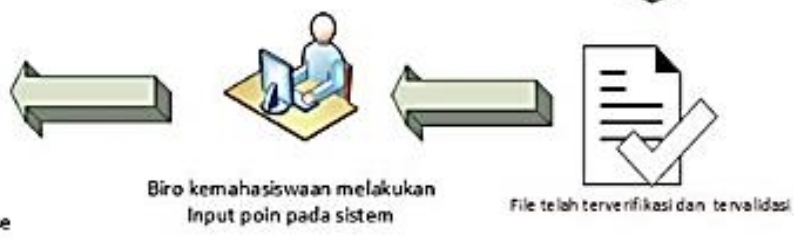

Gambar 1 Skema Alur Sistem Informasi ePoint Kemahasiwaan

Skema alur sistem informasi ePoint yang dirancang pada penelitian ini tampak pada gambar 1. Selanjutnya, adalah tahapan coding \& testing. Pada tahapan ini, desain sistem yang sudah didetailkan pada tiap unit input dan output, akan dieksekusi dan diterjemahkan ke dalam source code. Analisa dan desain sistem diharapkan sudah benar-benar matang pada tahapan ini, sehingga alur sistem pada proses pengerjaan program tidak lagi direvisi dan diinterupsi.

\subsection{Analisis Kebaikan Luaran}

Perangkat lunak ePoint Kemahasiswaan yang akan dirancang dan dibangun merupakan salah satu bagian/ modul dari payung sistem informasi SKPI yang lebih besar. Sehingga ePoint akan dinilai kebaikannya dari kebaikan informasi yang dihasilkan. Ciri-ciri sebuah informasi yang baik menurut Mc. Leod (Sukamto \& Shalahuddin, 2013) adalah sebagai berikut:

1) Akurat, artinya informasi mencerminkan keadaan yang sebenarnya. Pengujian terhadap hal ini biasanya dilakukan melalui pengujian yang dilakukan oleh dua orang atau lebih yang berbeda-beda dan apabila hasil pengujian tersebut menghasilkan hasil yang sama, maka dianggap data tersebut akurat.

2) Tepat waktu, artinya informasi itu harus tersedia atau ada pada saat informasi tersebut diperlukan, tidak besok atau tidak beberapa jam lagi.

3) Relevan, artinya informasi yang diberikan harus sesuai dengan yang dibutuhkan. Kalau kebutuhan informasi ini untuk suatu organisasi maka informasi tersebut harus sesuai dengan kebutuhan informasi diberbagai tingkatan dan bagian yang ada dalam organisasi tersebut.

4) Lengkap, artinya informasi harus diberikan secara lengkap.

Sedangkan menurut Joel Palmius dalam "Criteria for Measuring and Comparing Information Systems" , evaluasi sistem informasi (hasil agregat artikel mengenai IS di Google Scholar) dikelompokkan dalam 3 kategori (Palmius, 2017):

1) Economical benefit, such as return of investment

2) Usability measurements, mainly of interfaces

3) Measurements of user and/ or customer satisfaction

Sehingga berdasarkan 3 kategori di atas, penilaian kebaikan aplikasi ePoint akan dilakukan menggunakan lembar evaluasi yang menampung penilaian sebagai berikut: 1) Penilaian internal oleh peneliti dan tim pengembang aplikasi untuk menilai economical benefit 2) 
Penilaian oleh pengguna terhadap usability measurements dan measurements of user satisfaction. Evaluasi akan dilakukan di masa mendatang pada penelitian selanjutnya.

\section{HASIL DAN PEMBAHASAN}

\subsection{Desain Sistem}

Perancangan desain sistem dirancang berdasarkan hasil analisa yang telah dilakukan, maka dibuatlah perancangan sistem informasi berbasis web menggunakan framework codeigniter dan MySQ1 sebagai basis datanya. Perancangan dilakukan dengan pembuatan model terstruktur yang berorientasi pada proses yaitu menggunakan context diagram. Sehingga melalui gambar tersebut peranan masing-masing pengguan sistem dapat digambarkan dengan baik. Dalam sistem informasi ini ada 4 peranan level pengguna : biro kemahasiswaan, jurusan, mahasiswa dan super administrator. Fitur atau fungsional yang dikembangkan pada sistem informasi ini ada 3 (tiga), yaitu:

1. pengelolaan data kegiatan,

2. Penegelolaan data sertifikat,

3. Pengelolaan data poin.

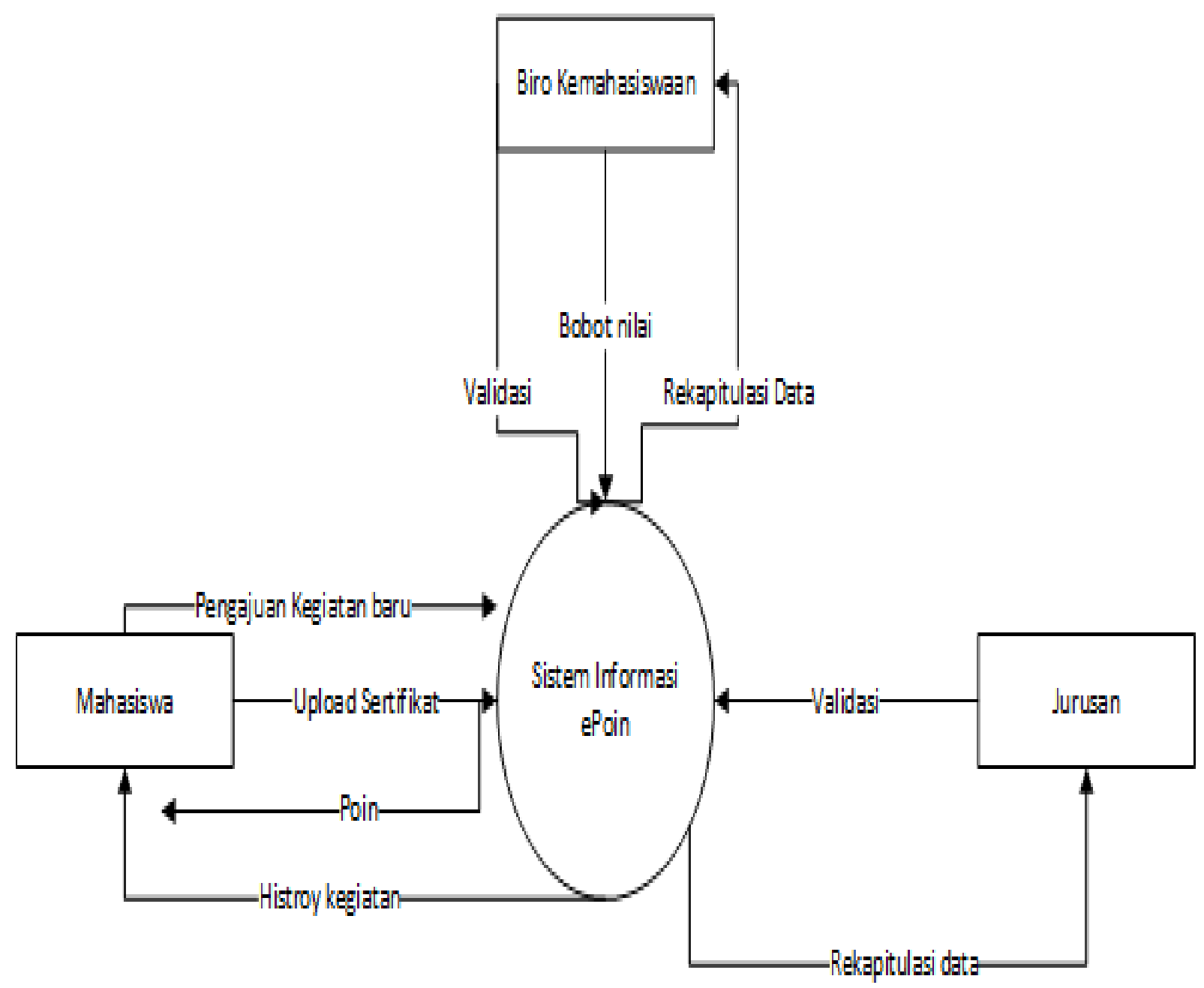

Gambar 2 Diagram Context ePoint 


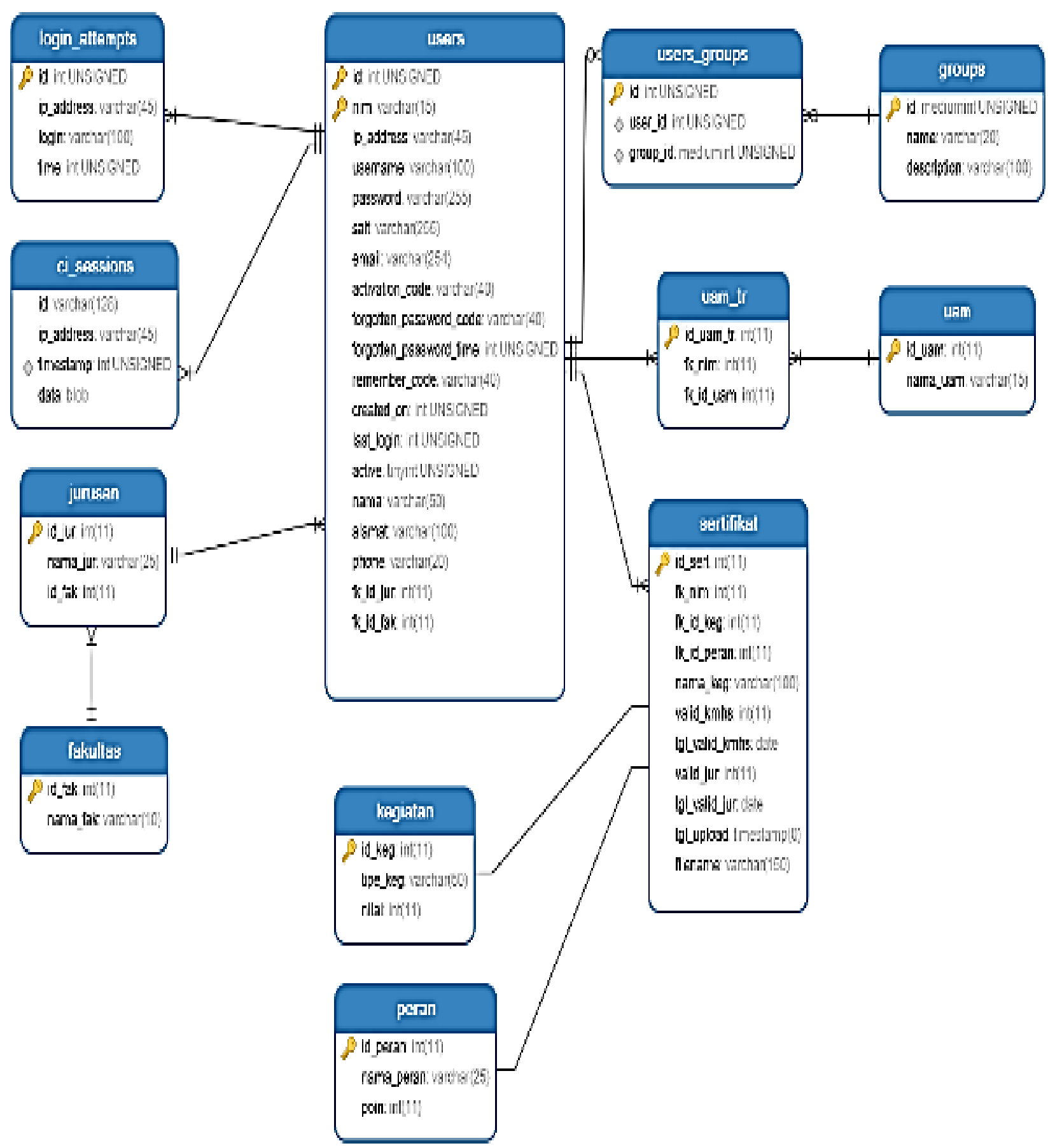

Gambar 3 Physical Data model ePoint Kemahasiswaan UKWK

\subsubsection{Desain Database}

Perancangan database dibuat berdasarkan kebutuhan sistem informasi ePoint kemahasiswaan UKWK. Dalam proses perancangan didapatkan ada 12 tabel database yang saling berelasi, seperti pada gambar berikut yang mengambarkan relasi antar tabel yang dibutuhkan dalam menunjang pembentukan system. 
URL : https://jurnal.machung.ac.id/index.php/kurawal

Tabel 1 Ilustrasi penilaian kegiatan mahasiswa

\begin{tabular}{|c|c|c|c|}
\hline NIM & Kegiatan & Keterangan & Poin \\
\hline \multirow[b]{2}{*}{201633002} & \multirow[b]{2}{*}{ Kuliah Umum } & Jenis Kegiatan : seminar & 50 \\
\hline & & Peran : peserta & 70 \\
\hline \multirow{2}{*}{201631001} & \multirow{2}{*}{ Kuliah Umum } & Jenis Kegiatan : seminar & 50 \\
\hline & & Peran : panitia & 100 \\
\hline \multirow{2}{*}{201433001} & \multirow{2}{*}{ Shasano } & $\begin{array}{c}\text { Jenis Kegiatan : Kegiatan } \\
\text { UAM }\end{array}$ & 50 \\
\hline & & Peran : Peserta & 70 \\
\hline
\end{tabular}

\subsubsection{Desain Pemberian Bobot Nilai}

Tahapan ini dilakukan perancangan skema penilaian yang berjalan pada sistem. Skema penilaian secara umum di dasarkan pada jenis aktifitas atau kegiatan yang di ikuti oleh mahasiswa dan peranan mahasiswa dalam aktifitas atau kegiatan tersebut. Tabel 1 berikut ini adalah contoh ilustrasi skema penilaian kegiatan dari mahasiswa yang didasarkan pada dua aspek kategori : jenis kegiatan dan peranan dalam kegiatan.

\subsubsection{Desain Antarmuka Prototype}

Pada tahap ini akan dibuat prototype sistem yang didasarkan pada kebutuhan fitur dan perancangan pada tahapan sebelumnya.

Desain antarmuka pada sistem informasi dibagi berdasarkan level akses pengguna. Pada gambar 4 adalah tampilan pada halaman utama sistem informasi.

Desain antarmuka akan disesuikan dengan level dari pengguna yang melakukan akses ke sistem. informasi ePoint Kemahasiswaan. Berikut ini adalah gambar tampilan dari desain dashboard untuk level super administrator.

Perancangan sidebar menu juga disesuikan dengan level akses pengguna, memiliki fungsi untuk menampung semua fitur menu yang ada di sistem informasi yang ada di setiap level pengguna.

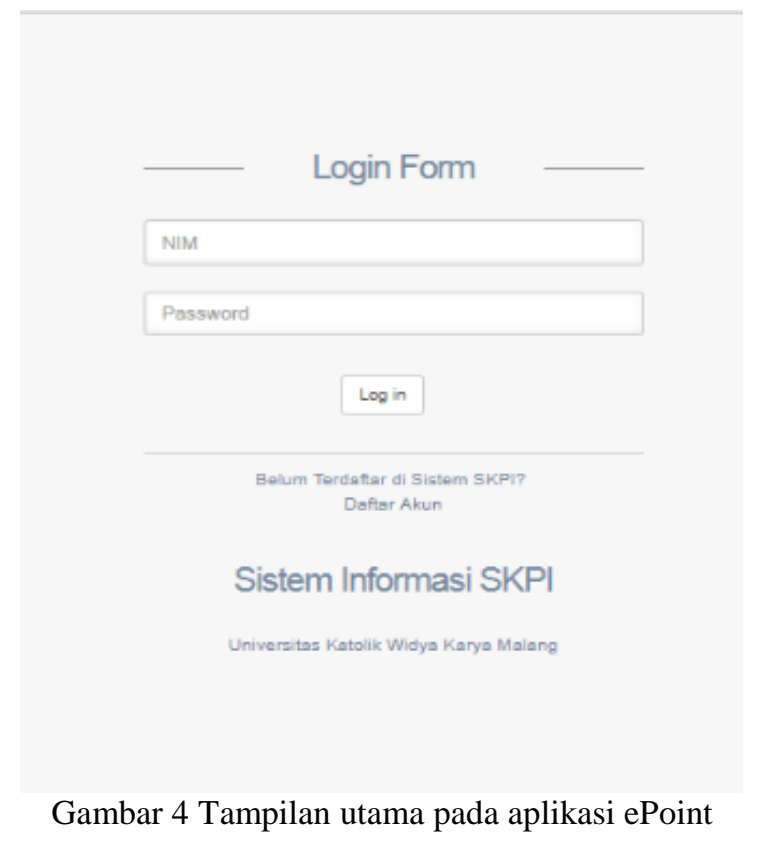




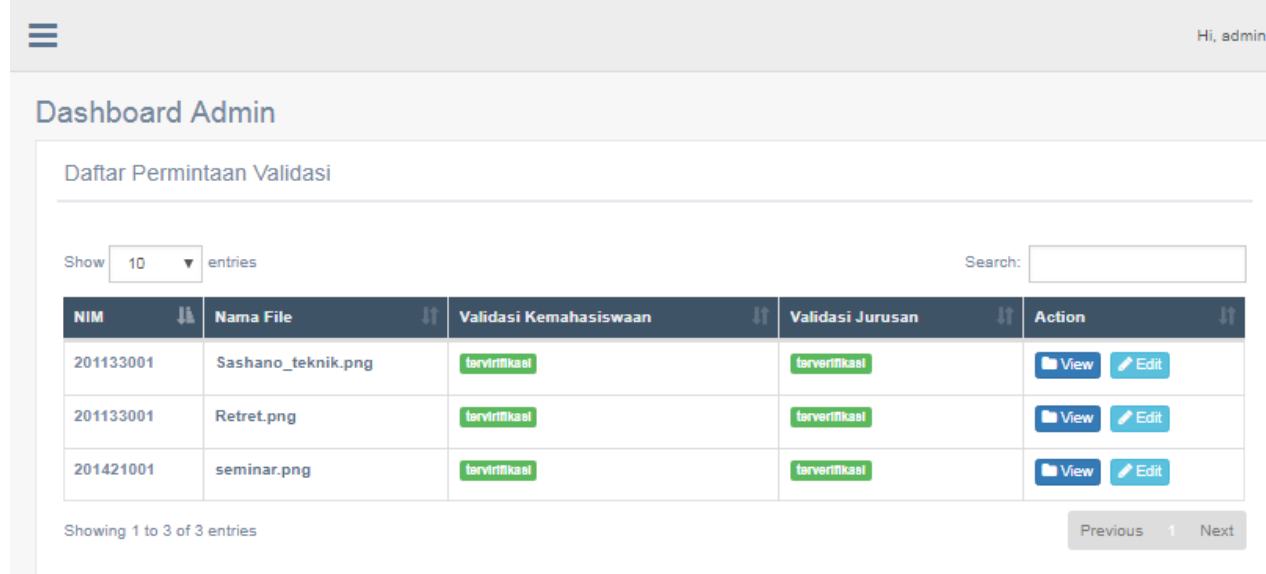

Gambar 4 Desain dashsboard

\section{Administrator}

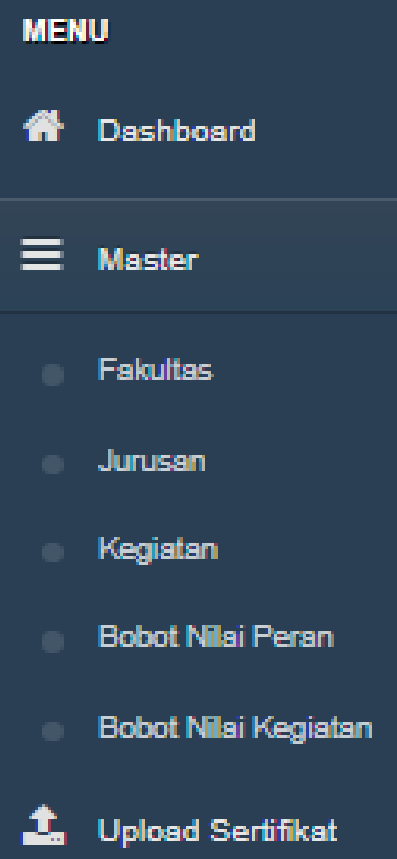

Gambar 5 Tampilan sidebar menu

Perancangan desain form yang akan digunakan untuk melakukan verifikasi data yang diunggah mahasiswa. Didalam form ini pengguna dapat menambahkan catatan bagi mahasiswa.

Perancangan desain laporan rekapitulasi poin mahasiswa di tampilkan dalam format tabel yang memudahkan pengguna dalam melihat keseluruhan isi data. 


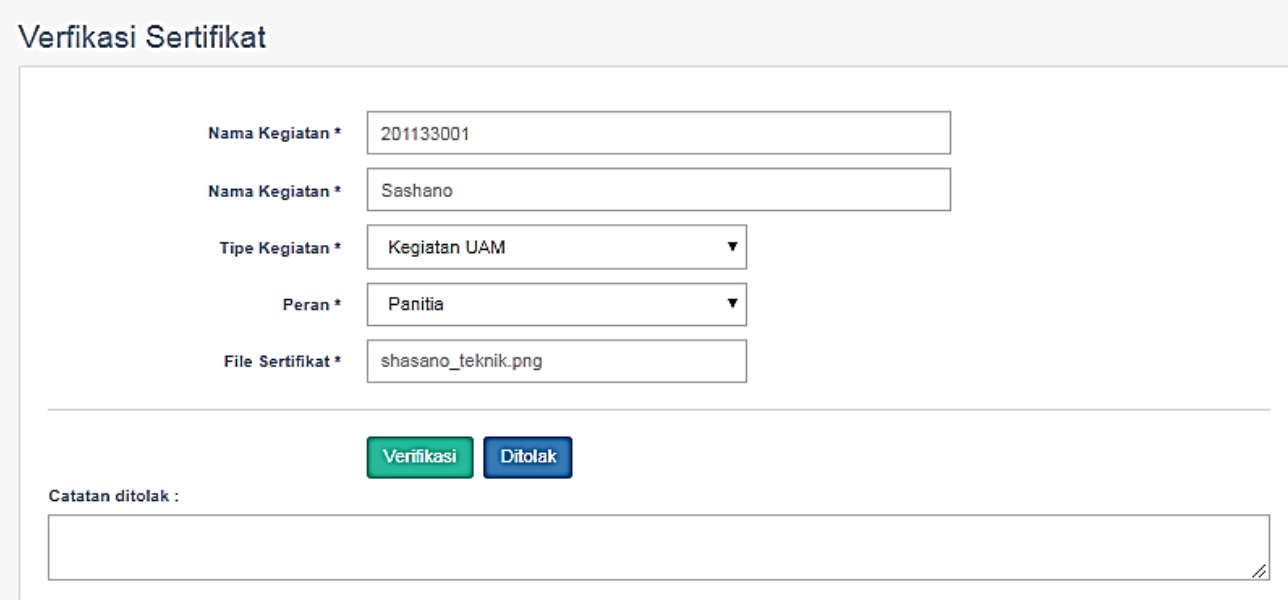

Gambar 6. Desain validasi dan verifikasi data level biro kemahasiswaan / jurusan

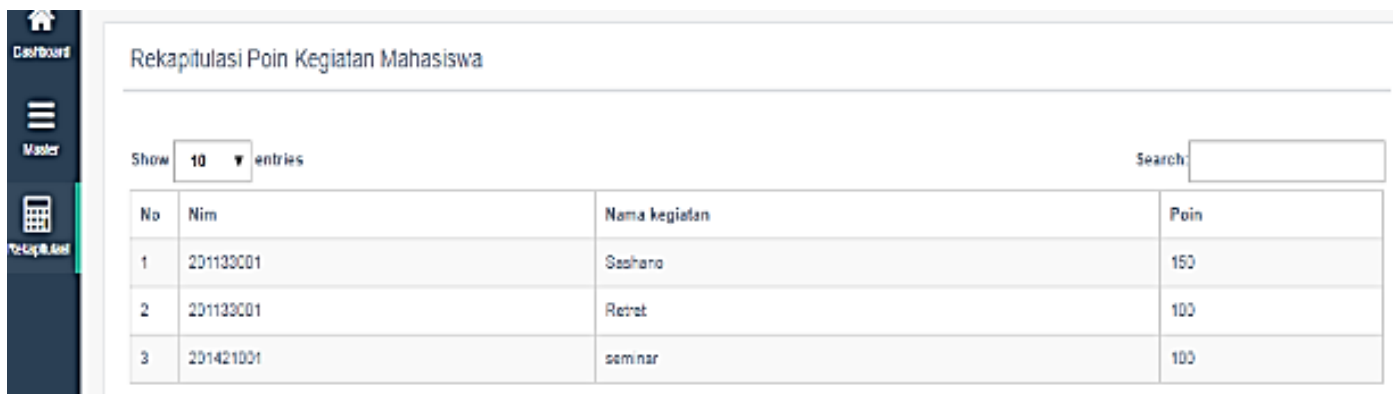

S.arng 1 \% 3 of 3 enties

Gambar 7 Desain rekapitulasi poin data level biro kemahasiswaan / jurusan

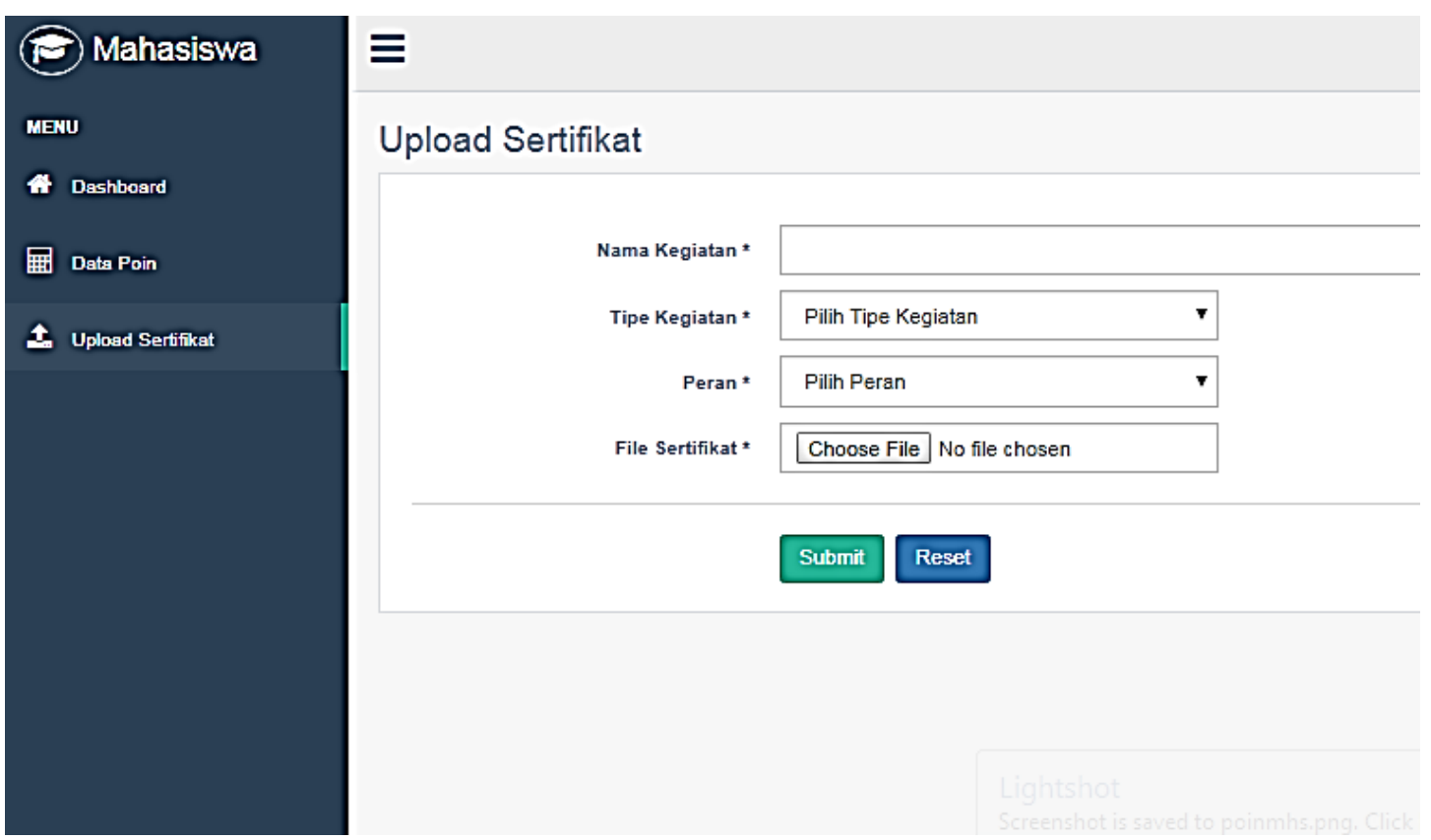

Gambar 8 Desain form upload kegiatan 


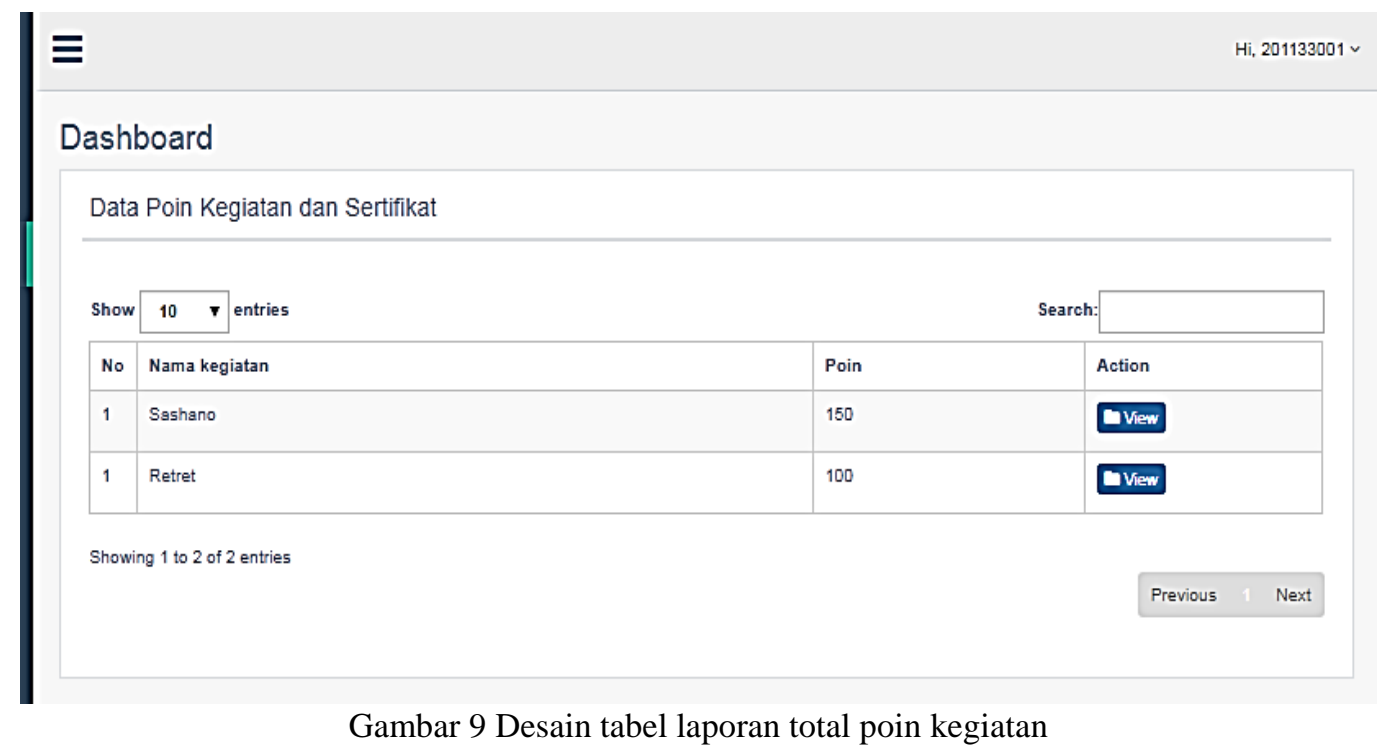

Perancangan desain form unggah ini digunakan pada saat mahasiswa ingin menambahkan aktifitas kegiatan baru pada sistem.

Perancangan desain tabel ini di gunakan untuk menampilkan perekaman data dari mahasiswa yang telah mendapatkan validasi dan mem-peroleh penilaian.

\section{KESIMPULAN}

Hasil penelitian ini dapat kami simpulkan bahwa proses pencatatan aktifitas kegiatan mahasiswa sebagai salah satu unsur pendukung dari SKPI dapat di bantu secara terkomputerisasi dan tercatat dalam sebuah sistem database. Selain itu target luaran dari penelitian ini adalah terciptanya prototype sistem informasi ePoin kegiatan mahasiswa di UKWK , disamping itu luaran dari penelitian ini adalah publikasi dalam bentuk jurnal pada jurnal wawasan.

\section{REFERENSI}

[1] Kemendikbud, R. I, 2014, Permendikbud Nomor 81

[2] Palmius, Joel, 2017, Criteria for measuring and comparing information systems, http://www.palmius.com/joel/text/IRIS-30-final.pdf

[3] Pressman S, R, 2010, Software Engineering: A Practitioner's Approach (Vol. 7th edition). New York: McGraw-Hill

[4] SKPI, 2017, SKPI: KKNI Kemristekdikti, http://kkni.kemenristekdikti.go.id/skpi

[5] Sukamto, R., \& Shalahuddin, M, 2013, Rekayasa Perangkat Lunak, Bandung 